\title{
Optimization techniques for the design of high-performance fibre-reinforced concrete
}

\author{
B. L. Karihaloo • D. Lange-Kornbak
}

Published online: 30 May 2008

(C) Springer-Verlag 2008

Erratum to: Struct Multidisc Optim (2001) 21:32-39

DOI 10.1007/s001580050165

A slightly shorter version of the above paper under the title "Optimum design of high-performance steel fibrereinforced concrete mixes" had appeared in the Proc Int Symp "Brittle Matrix Composites 6," A M Brandt, V C Li, I H Marshall eds, ZTUREK RSI Warsaw and Woodhead Publ, Cambridge UK, 2000, 3-16. The first author deeply regrets that due to an oversight this fact was not acknowledged in the paper.

The online version of the original article can be found at http://dx.doi.org/10.1007/s001580050165.

B. L. Karihaloo $(\bowtie)$

Institute of Theoretical Applied and Computational

Mechanics, School of Engineering, Cardiff University,

The Parade, Cardiff, CF24 3AA, UK

e-mail: karihaloob@Cardiff.ac.uk

D. Lange-Kornbak

Division of Building Technology and Productivity,

Danish Building Research Institute,

DK-2970 Hørsholm, Denmark

e-mail:dlk@giantcode.com 